\title{
Crystal Structures of two Imidazole Derivatives
}

P. Ambalavanan, K. Palani , M. N. Ponnuswamyand, R. A. Thirumuruhan , H. S. Yathirajan , B. Prabhuswamy , C. R. Raju , P. Nagaraja \& K. N. Mohana

To cite this article: P. Ambalavanan , K. Palani , M. N. Ponnuswamyand, R. A. Thirumuruhan, H. S. Yathirajan , B. Prabhuswamy , C. R. Raju , P. Nagaraja \& K. N. Mohana (2003) Crystal Structures of two Imidazole Derivatives, Molecular Crystals and Liquid Crystals, 393:1, 75-82, DOI: 10.1080/10587250307074

To link to this article: https://doi.org/10.1080/10587250307074

曲 Published online: 18 Oct 2010.

Submit your article to this journal 준

山 Article views: 66

Q View related articles ¿

4 Citing articles: 1 View citing articles 준 


\title{
CRYSTAL STRUCTURES OF TWO IMIDAZOLE DERIVATIVES
}

\author{
P. Ambalavanan, K. Palani, M. N. Ponnuswamy, \\ and R. A. Thirumuruhan \\ Department of Crystallography and Biophysics, University \\ of Madras, Guindy Campus, Chennai-600 025, India \\ H. S. Yathirajan, B. Prabhuswamy, C. R. Raju, P. Nagaraja, \\ and K. N. Mohana \\ Department of Studies in Chemistry, University of Mysore, \\ Manasagangotri, Mysore-570 006, India
}

\begin{abstract}
2-n-Butyl-5-chloro-3H-imidazole-4-carbaldehyde (BCIC), $\mathrm{C}_{8} \mathrm{H}_{11} \mathrm{ClN}_{2} \mathrm{O} . \mathrm{F} . \mathrm{W} .=$ 186.64, monoclinic, $P 2_{1} / c, \quad a=7.2617(3) \AA, \quad b=13.2067(6) \AA, \quad c=9.8491(4) \AA$ $\beta=101.76(1)^{\circ}, \quad V=924.74(7) \AA^{3}, \quad Z=4, \quad D_{\text {cal }}=1.341 \mathrm{Mgm}^{-3}, \quad \mu=0.367 \mathrm{~mm}^{-1}$, $F_{\text {Ooo }}=392, \lambda(M o K \alpha)=0.71073 \AA$, final $R 1$ and $w R 2$ are 0.049 and 0.126 , respectively. 2-n-Butyl-4-chloro-1 [(2'-cyanobiphenyl-4-yl)methyl]-5-hydroxymethyl imidazole (BCCI), $C_{22} \mathrm{H}_{22} \mathrm{ClN}_{3} \mathrm{O}, \mathrm{F} . W .=379.88$, triclinic, $P \overline{1}, a=8.198(2) \AA$, $b=10.997(3) \AA, c=11.524(2) \AA, \alpha=90.83(2)^{\circ}, \beta=94.31(2)^{\circ}, \gamma=109.45(2)^{\circ}, V=$ 976.0(2) $\AA^{3}, Z=2, D_{\text {cal }}=1.293 \mathrm{Mgm}^{-3}, \mu=1.856 \mathrm{~mm}^{-1}, F_{\text {ooo }}=400, \lambda(\mathrm{CuK \alpha})=$ $1.5418 \AA$, final $R 1$ and $w R 2$ are 0.081 and 0.239 , respectively. The imidazole ring in both the molecules is planar. The $n$-butyl group adopts a bent conformation in $B C I C$ where it is in extended conformation in BCCI. The biphenyl ring system orients at an angle of $45.1(1)^{\circ}$ in BCCI. The molecules are stabilized by $N-H \ldots N$ and $O-H \ldots N$ type hydrogen bonds in addition to van der Waals forces.
\end{abstract}

Keywords: crystal structure; conformation; hydrogen bonding; BCIC; BCCI

One of the authors P. Ambalavanan would like to thank UGC for providing FDP under IX plan period and also Commissioner of Collegiate Education, Chennai-600 006 for giving permission to carry out the research work in the Department of Crystallography and Biophysics, University of Madras. 


\section{INTRODUCTION}

Imidazole is a heterocyclic five-membered ring containing nitrogen atoms. Various imidazole derivatives are found to possess biological activities. Interestingly, it is to be noted that biotin, a heterocyclic sulfur-containing B-complex vitamin, is fused of imidazole and thiophene rings and participates as a coenzyme in the carboxylation reaction [1].

Imidazole is a protonated five-membered ring, which promotes chemical reactions depending on the specific physical conditions at enzyme catalytic sites [2]. Imidazoles and benzimidazoles are the components of important structures used in pharmaceuticals, agrochemicals, dyestuffs, and high temperature polymer products. The crystal structure of cis-1-\{[4(1-Imidazolylmethyl) cyclohexyl] methyl\} imidazole-succinic acid complex has been determined since it is an active nonsteroidal aromatase inhibitor $[3,4]$.

With a view to understand the conformation of the imidazole moiety and the influence of substituents at different positions of this fivemembered ring, the crystal structure determination of two imidazole derivatives have been carried out. The chemical diagrams of BCIC and BCCI are shown in Figure 1.

\section{X-RAY DATA COLLECTION, STRUCTURE SOLUTION, AND REFINEMENT}

\section{Data Collection}

Intensity data were collected on a Siemens SMART CCD [5] area detector diffractometer using graphite monochromated MoK $\alpha$ radiation for BCIC.
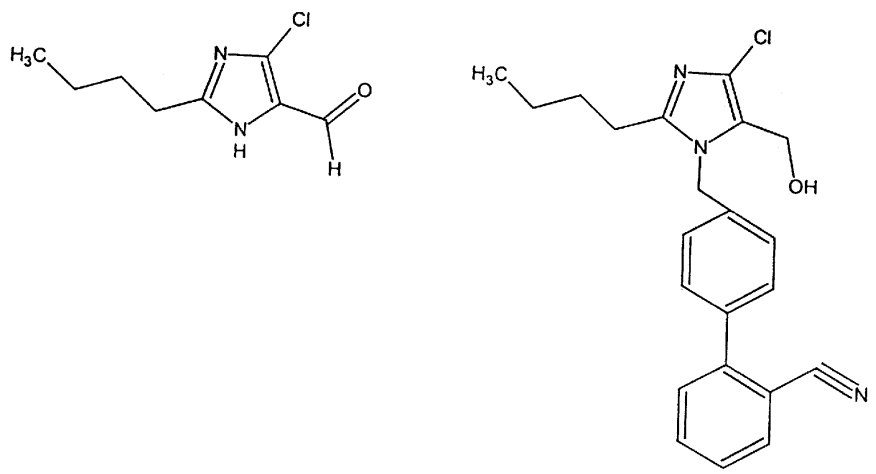

FIGURE 1 Chemical diagrams of BCIC and BCCI. 
The entire data collection was covered over a hemisphere of reciprocal space by a combination of three sets of exposure, each having a different $\phi$ angle $\left(0,88\right.$, and $\left.180^{\circ}\right)$ for the crystal and each exposure time of $10 \mathrm{~s}$ covered $0.3^{\circ}$ in $\omega$. The crystal-to-detector distance was $4 \mathrm{~cm}$ and the detector swing angle was $-35^{\circ}$. Coverage of unique set was complete by over $99 \%$. Crystal decay, monitored by repeating thirty initial frames at the end of the data collection and analyzing the duplicate reflections, was found to be negligible.

For BCCI, the data were collected on a CAD4 diffractometer [6] using graphite monochromated $\mathrm{CuK} \alpha$ radiation. Accurate unit cell parameters were derived from least-squares analysis using 25 reflections. In order to check the intensity deterioration due to the radiation damage or crystal degradation, three standard reflections were monitored for every $1 \mathrm{~h}$ or for every hundred reflections, whichever is the earliest. The intensity data were corrected for Lorentz, polarization, and absorption effects [7].

\section{Structure Solution and Refinement}

Both the structures were solved using direct methods in SHELXS97 [8] and refined in SHELXL97 [9]. Hydrogen atoms were placed at the calculated positions but not refined. The final cycles of full-matrix least-squares refinement were carried out applying anisotropic thermal parameters for all nonhydrogen atoms. The geometrical parameters were calculated using PARST [10], and the molecular graphics were drawn through ZORTEP [11].

\section{RESULTS AND DISCUSSION}

The crystal and refinement data are given in Table I. Figures 2 and 3 show the ZORTEP plot of the molecules of BCIC and BCCI with thermal ellipsoids at $30 \%$ probability level. The bond lengths and bond angles of the imidazole moiety in BCIC and BCCI are comparable with the standard values $[12,13]$. The C-C1 distances (C4-C112=) 1.712(2) $\AA$ and 1.723(4) are within the range of values reported in the literature [14].

In BCIC molecule, the imidazole ring, carbaldehyde group, and $\mathrm{C} 1$ atom lie in the same plane except the n-butyl chain which adopts a bent conformation as can be seen from the conformational angles (N3-C2-C6$\mathrm{C} 7=) 63.5(2)^{\circ},(\mathrm{C} 2-\mathrm{C} 6-\mathrm{C} 7-\mathrm{C} 8=) 61.8(2)^{\circ}$, and $(\mathrm{C} 6-\mathrm{C} 7-\mathrm{C} 8-\mathrm{C} 9=) 71.0(2)^{\circ}$. In BCCI molecule, the 2-n-butyl substitution at $\mathrm{C} 2$ lies almost in the plane of the imidazole moiety. This facilitates the atom $\mathrm{C} 7$ to form a C-H... N hydrogen bonding with the imidazole nitrogen N3 (C7 . . N3=)2.861(6) and $\left(\mathrm{C} 7-\mathrm{H} 7 \mathrm{~B} \ldots \mathrm{N} 3=88.3(3)^{\circ}\right)$. The n-butyl group of BCCI is in an 
TABLE I Crystal Data for BCIC and BCCI

\begin{tabular}{|c|c|c|}
\hline Parameter & BCIC & BCCI \\
\hline Empirical formula & $\mathrm{C}_{8} \mathrm{H}_{11} \mathrm{Cl} \mathrm{N} \mathrm{N}_{2} \mathrm{O}$ & $\mathrm{C}_{22} \mathrm{H}_{22} \mathrm{Cl} \mathrm{N} \mathrm{N}_{3} \mathrm{O}$ \\
\hline Formula weight & 186.64 & 379.88 \\
\hline Temperature $(\mathrm{K})$ & $293(2)$ & $293(2)$ \\
\hline Wavelength & $0.71073 \AA$ & $1.5418 \AA$ \\
\hline Crystal system & Monoclinic & Triclinic \\
\hline Space group & $\mathrm{P} 21 / \mathrm{c}$ & $\mathrm{P} \overline{1}$ \\
\hline \multirow[t]{6}{*}{ Unit cell dimensions } & $\mathrm{a}=7.2617(3) \AA$ & $\mathrm{a}=8.198(2) \AA$ \\
\hline & $\mathrm{b}=13.2067(6) \AA$ & $\mathrm{b}=10.997(3) \AA$ \\
\hline & $\mathrm{c}=9.8491(4) \AA$ & $\mathrm{c}=11.524(2) \AA$ \\
\hline & & $\alpha=90.83(2)^{\circ}$ \\
\hline & $\beta=101.76(1)^{\circ}$ & $\beta=94.31(2)^{\circ}$ \\
\hline & & $\gamma=109.45(2)^{\circ}$ \\
\hline Volume & $924.74(7) \AA^{3}$ & $976.0(4) \AA^{3}$ \\
\hline Z & 4 & 2 \\
\hline Calculated density & $1.341 \mathrm{Mg} / \mathrm{m}^{3}$ & $1.293 \mathrm{Mg} / \mathrm{m}^{3}$ \\
\hline Absorption coefficient & $0.367 \mathrm{~mm}^{-1}$ & $1.856 \mathrm{~mm}^{-1}$ \\
\hline $\mathrm{F}(000)$ & 392 & 400 \\
\hline Crystal size & $0.24 \times 0.14 \times 0.08 \mathrm{~mm}$ & $0.35 \times 0.20 \times 0.10 \mathrm{~mm}$ \\
\hline$\theta$ - range for data collection & 2.62 to $28.29^{\circ}$ & 3.85 to $71.92^{\circ}$ \\
\hline \multirow[t]{3}{*}{ Index ranges } & $-9 \leq \mathrm{h} \leq 9$ & $-10 \leq h \leq 9$ \\
\hline & $-13 \leq \mathrm{k} \leq 17$ & $0 \leq \mathrm{k} \leq 13$ \\
\hline & $-11 \leq 1 \leq 13$ & $-14 \leq 1 \leq 14$ \\
\hline Reflections collected & 6383 & 4023 \\
\hline Independent reflections & $2268[\mathrm{R}(\mathrm{int})=0.0597]$ & $3821[\mathrm{R}(\mathrm{int})=0.0891]$ \\
\hline Observed reflections & 1664 & 2423 \\
\hline \multicolumn{3}{|l|}{$[\mathrm{I}>2 \sigma(\mathrm{I})]$} \\
\hline Refinement method & $\begin{array}{l}\text { Full-matrix least-squares } \\
\text { on } \mathrm{F}^{2}\end{array}$ & $\begin{array}{l}\text { Full-matrix least-squares } \\
\text { on } \mathrm{F}^{2}\end{array}$ \\
\hline Goodness-of-fit on $\mathrm{F}^{2}$ & 0.946 & 1.086 \\
\hline Final R-indices $[\mathrm{I}>2 \sigma(\mathrm{I})]$ & $\mathrm{R}_{1}=0.049, \mathrm{wR}_{2}=0.126$ & $\mathrm{R}_{1}=0.081, \mathrm{wR}_{2}=0.239$ \\
\hline R-indices (all data) & $\mathrm{R}_{1}=0.0634, \mathrm{wR}_{2}=0.1333$ & $\mathrm{R}_{1}=0.1247, \mathrm{wR}_{2}=0.2757$ \\
\hline
\end{tabular}

extended conformation as evidenced by the conformational angles (N1-C2$\mathrm{C} 6-\mathrm{C} 7=) 176.4(5)^{\circ} . \quad(\mathrm{C} 2-\mathrm{C} 6-\mathrm{C} 7-\mathrm{C} 8=)-177.1(5)^{\circ}, \quad$ and $(\mathrm{C} 6-\mathrm{C} 7-\mathrm{C} 8-\mathrm{C} 9=)$ $178.5(5)^{\circ}$.

The imidazole ring is planar in both the molecules (maximum deviation $0.005(2) \AA$ for N3 in BCIC and 0.008(5) $\AA$ for C5 in BCCI). This is also supported by the minimum $\mathrm{q}_{2}$ values of 0.009(2) for BCIC and 0.005(4) for BCCI [10]. In BCCI, the sum of the bond angles around N1 is $360.0^{\circ}$, which confirms that the atom N1 is in $s p^{2}$ hybridized state. The bond length N1C13 is comparable with the standard value [15].

In BCCI, the two phenyl rings (biphenyl ring system) are planar (maximum deviation $\pm 0.014(5) \AA)$, and the mutual orientation of these phenyl 


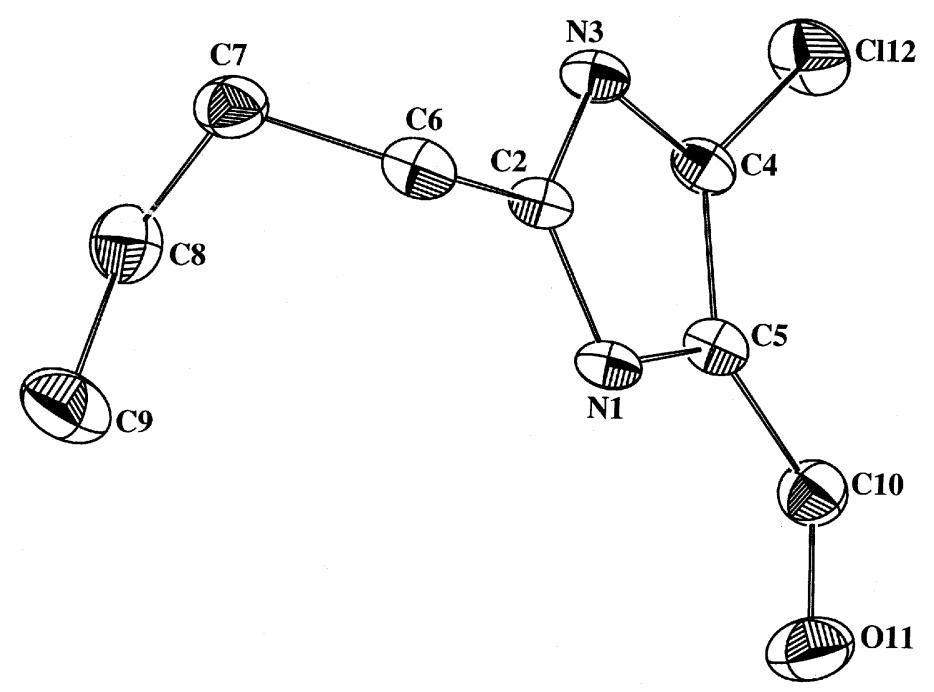

FIGURE 2 ZORTEP diagram of BCIC.

rings is $45.1(1)^{\circ}$, a common feature observed in many biphenyl derivatives [16]. In the biphenyl ring system, the endocyclic bond angles at C16 and C20 are contracted to $118.0(4)^{\circ}$ and $118.3(4)^{\circ}$, respectively, due to steric hindrance between the rings. The cyano group $(\mathrm{C} \equiv \mathrm{N})$ attached to the phenyl ring is linear $\left(\mathrm{C} 25-\mathrm{C} 26-\mathrm{N} 27=177.8(5)^{\circ}\right)$. The two phenyl rings (biphenyl group) are oriented at angles of $85.3(2)^{\circ}$ and $80.6(2)^{\circ}$ with respect to the imidazole moiety.

In BCIC, the molecules are linked by a three-dimensional network of $\mathrm{N}-\mathrm{H} \ldots \mathrm{N}$ type hydrogen bonds. But the $\mathrm{O}-\mathrm{H} \ldots \mathrm{N}$ type hydrogen bonds stabilize the molecules in BCCI crystal. Weak intermolecular interactions of the type $\mathrm{C}-\mathrm{H} \ldots \mathrm{O}$ and $\mathrm{C}-\mathrm{H} \ldots \mathrm{N}$ are also observed in the crystals of both BCIC and BCCI.

\section{Preparation of BCIC}

A mixture of glycine $(0.55 \mathrm{~mol}, 41.7 \mathrm{~g})$, methanol $(175.0 \mathrm{ml})$, and water $(10 \mathrm{ml})$ was cooled to $0^{\circ} \mathrm{C}$ under stirring. Two drops of $30 \% \mathrm{NaOH}$ was added into the mixture ( $\mathrm{pH}$ 8.0-9.5). To this mixture, a solution of methyl pentanimidate $(0.55 \mathrm{~mol}, 64.0 \mathrm{~g})$ in toluene $(106 \mathrm{ml})$ was added and stirred for $15 \mathrm{~min}$. The mixture was stirred overnight. The $\mathrm{pH}$ of the mixture was then adjusted from 10.1 to 7.0 (conc. $\mathrm{H}_{2} \mathrm{SO}_{4}$ ) and charged with toluene $(500 \mathrm{ml})$. The methanol was distilled completely and the mixture was cooled to $0^{\circ} \mathrm{C}$. To the cooled mixture was added with $\mathrm{POCl}_{3}$ (1.55 mol, 


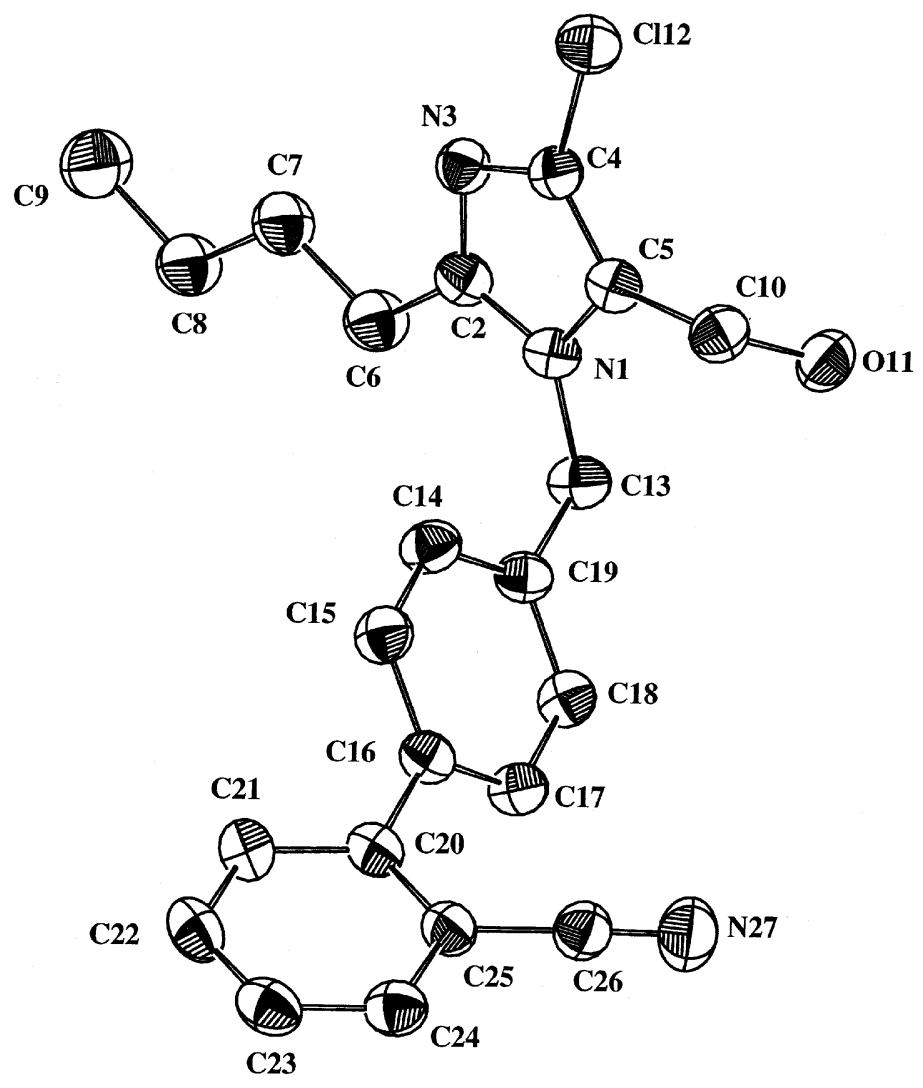

FIGURE 3 ZORTEP diagram of BCCI.

$238.0 \mathrm{~g})$ and $\mathrm{DMF}(1.55 \mathrm{~mol}, 113.6 \mathrm{~g})$ at $80^{\circ} \mathrm{C}$. The mixture was heated at $100^{\circ} \mathrm{C}$ for $2 \mathrm{~h}$, cooled to room temperature and poured into ice water $(370 \mathrm{ml})$ (temp. $30^{\circ} \mathrm{C}$ ) with vigorous stirring for $2 \mathrm{~h}$. The organic layer was separated after adjusting the $\mathrm{pH}$ of the mixture of 7.2. It was washed with water $(2 \times 50 \mathrm{ml})$, dried over anhydrous $\mathrm{Na}_{2} \mathrm{SO}_{4}$ concentrated, and cooled to $-10^{\circ} \mathrm{C}$ for $2 \mathrm{~h}$. The product separated was filtered off, washed with ice-cold toluene, and dried to get $57.5 \mathrm{~g}$ (55\%) of pure product. It was recrystallized from $\mathrm{CC} 14$ to get white needles.

\section{Preparation of $\mathrm{BCCl}$}

A solution of 2-n-butyl-4-chloro-5-formylimidazole (0.05 mol, $9.32 \mathrm{~g})$ in methanol $(40 \mathrm{ml})$ was cooled at $0^{\circ} \mathrm{C}$. Sodiumborohydride $(0.0125 \mathrm{~mol}$, $0.4727 \mathrm{~g}$ ) was added slowly with stirring. the reaction mixture was then 
stirred at room temperature for 2-3h. After completion of reaction (TLC), the mixture was concentrated to about $10 \mathrm{ml}$ and poured into ice water $(100 \mathrm{ml})$. The white product formed was filtered, washed, with water and dried under vacuum at $50^{\circ} \mathrm{C}$ to get $90 \%$ (8.4 g) of 2-n-butyl-4-chloro-5hydroxymethyl imidazole. To a suspension of sodium methoxide $(0.03 \mathrm{~mol}$, $1.62 \mathrm{~g})$ in DMF (25 ml) was added 2-n-butyl-4-chloro-5-hydroxymethylimidazole $(0.03 \mathrm{~mol}, 5.655 \mathrm{~g})$ in DMF $(25 \mathrm{ml})$. The mixture was stirred at $25^{\circ} \mathrm{C}$ for $30 \mathrm{~min}$. To this mixture was added in drops, a solution of 4-bromomethyl-2'-cyanobiphenyl (0.025 mol, $6.80 \mathrm{~g})$ in DMF (25 ml). The mixture was stirred at room temperature for $24 \mathrm{~h}$. The mixture was evaporated to a residue under vacuum and dissolved in ethyl acetate $(70 \mathrm{ml})$, washed with brine solution $(20 \mathrm{ml})$, water $(50 \mathrm{ml})$, dried using $\mathrm{Na}_{2} \mathrm{SO}_{4}$, and evaporated to get a crude product which was purified by column chromatography using n-hexane-ethylacetate mixture (7:2) as the eluent to get the title product in $40 \%$ yield (3.11 g). It was recrystallized from $\mathrm{CCl}_{4}$ to get white needles. Both BCCI and BCIC are white crystalline solids and serve as important key intermediates for preparing antihypertensive drug Losartan potassium [17]. Both compounds are soluble in chloroform, tetrahydrofuran, acetone, etc. It answers the tests for primary alcoholic and chloro groups.

\section{REFERENCES}

[1] Satyanarayana, U. (1999). Biochemistry, (Calcutta: Books and Allied (P) Ltd.).

[2] Voet, D., \& Voet, G. (1995). Biochemistry, 2nd edn., (New York: John Wiley and Sons).

[3] Schiavo, D. M., Green, J. D., Triana, V. M., Spaet, R., \& Zaidi, I. (1988). Fundam. Appl. Toxicol., 10, 329.

[4] Bullion, K. A., Osawa, Y., \& Braun, D. G. (1990). Endocrino. Res., 16, 225.

[5] Siemens. (1996). SMART Software Reference Manual. (Madison, WI: Siemens Analytical X-ray Instruments, Inc.).

[6] Enraf-Nonius. (1994). CAD-4 EXPRESS Software. (Delft, The Netherlands: EnrafNonius).

[7] Stout, G. H., \& Jenson, L. H. (1968). 'X-ray Structure Determination-A Practical Guide'(New York: Macmillan Company).

[8] Sheldrick, G. M. (1997). SHELXS97. Program for the Crystal Structure Solution, (Germany: University of Gottingen).

[9] Sheldrick, G. M. (1997). SHELXL97. Program for the Crystal Structure refinement, (Germany: University of Gottingen).

[10] Nardelli, M. (1983). Comput. Chem., 7, 95.

[11] Zsolnai, L. (1997). ZORTEP, An Interactive Graphics Crystal Structure Illustrations, (Germany: University of Heidelberg).

[12] Soriano-Garcia, M., Schatz-Levine, M., Toscano, R. A., \& Villena Iribe, R. (1990). Acta Cryst. C46, 1556.

[13] Koman, M., Jona, E., \& Maslejova, A. (1991). Acta Cryst. C47, 1206.

[14] Thirumurugan, R., Shanmuga Sundara Raj, S., Shanmugam, G., Fun, H. K., Raghukumar, V., \& Ramakrishnan, V. T. (1999). Acta Cryst. C55, 1522. 
[15] Allen, F. H., Kennard, O., Watson, D. G., Brummer, L., Orpen, A. G., \& Taylor, R. (1987). J. Chem. Soc. Perkin. Trans., II, S1-S19.

[16] Subbiah Pandi, A., Velmurugan, D., Raghukumar, V., Ramakrishnan, V. T., Shanmuga Sundara Raj, S., \& Fun, H. K. (2000). Cryst. Res. Technol., 35, 11.

[17] Griffiths, G. J., Hauck, M. B., Imwinkelried, R., Kohr, J., Roten, C. A., \& Stucky, G. C. (1999). J. Org. Chem., 64, 8084. 